\title{
Thwarting Plagiarism in the Humanities Classroom: Storyboards, Scaffolding, and a Death Fair
}

\author{
Mary Hale \\ Saint Mary's University \\ mary.hale@smu.ca
}

\begin{abstract}
Best practices research on plagiarism in the University classroom shows that modifying assignments and classroom environment can have a positive effect on lowering a student's desire to cheat. James Lang suggests four features of a learning environment that can be fostered to ameliorate a student's desire to cheat: mastery of the material for its own sake, low-stakes assignments, intrinsic motivations for learning and, a high expectation of success. Scaffolding has been shown to be a useful pedagogical technique for empowering students (fostering a high expectation of success) My past experience using a variety of visual classroom exercises (cartooning, mind-mapping, advertising campaigns, etc.) gave anecdotal evidence that artistic and visual assignments encouraged a level of engagement and collaboration across language and cultural boundaries not experienced in other types of assignments. I hypothesized that this level of engagement and collaboration could be used with scaffolding to motivate Lang's four features and experimented with the use of poster presentations and other visual and spatial assignments in a second year undergraduate Religious Studies course on Death. Very preliminary qualitative data support the hypothesis that, by addressing Lang's four features and incorporating scaffolding and visual assignments into the course, students are cheating less and learning more. This research strengthens the extant literature on the impact class environment and expectations have on plagiarism while also adding to the growing body of literature supporting the use of visual assignments, such as poster presentations, mind mapping, and storyboards in the Arts and Humanities.
\end{abstract}

Keywords: poster presentations in the Humanities, plagiarism in the University classroom, collaborative learning, scaffolding, mind-mapping, storyboards

\section{Introduction}

I reached the sanctity of my office, closed the door, sank into a chair, and made myself just breathe deeply and calmly for five minutes. I had just sat through an excruciating 45 minutes of student panel/presentations for my second-year Religious Studies course on Death and was struggling to exorcise the echo of five almost-identical papers delivered in five different monotones to what apparently had been a classroom of crickets masquerading as people. But even more distressing than student delivery and response were the papers themselves. The amount of plagiarism had become daunting. Where once I had one or two instances per seventy students per class, now it was at least ten out of seventy. And, even worse in my estimation, the number of papers that appeared to have been purchased were on the rise. It was not only that tracking down plagiarism and plagiarizers was tedious and time-consuming but, I also suspected that the increase was a reflection of classroom environment and course design. The student 
population had changed and it was possible that my classroom pedagogy had not changed quickly enough in response. This suspicion was bolstered by my ensuing reading on the subject - the results of which also raised the issue of complex culpability in regards to plagiarism. I found that, while a good deal of the research on plagiarism puts the responsibility for amelioration squarely on the student (Macdonald \& Carroll, 2006), there is emerging literature which holds other stakeholders (instructors and administrators, for example) equally, if not more, culpable (Lang, 2013).

\section{Rationale and Objectives}

As noted above, my students were not engaged by the paper presentation panel assignment that was, traditionally, the central assignment in the Death course. This disengagement was manifesting itself in lackluster panel presentations and a sharp rise in plagiarism. In addition, the student population had changed, and it was possible that students were coming to me with a different skill set than was manifest in previous student populations. Preliminary research showed that these issues could be linked.

My objective, then, became two-fold: first, was to find modify my classroom environment using pedagogical approaches that dissuade plagiarism and increased student engagement and quality of learning. I developed a curriculum based on a series of what I call "visual assignments" (poster presentations, storyboards, mind-mapping, etc.). The assignments are scaffolded to enhance the development of academic skill sets. The assignment as a whole is called the "Death Fair".

Second, I wanted to know what the implementation of this curriculum and pedagogical approach would tell me in light of some of the emergent literature on plagiarism, championed by James Lang. This perspective asserts that classroom environment and instructor pedagogy could play a role in a student's predilection for plagiarizing.

This paper reports on the preliminary findings regarding the effectiveness of that pedagogical project. As will be shown, plagiarism did, in fact, decrease after I implemented the project (see discussion). The "Death Fair" project utilized poster presentations as the culmination of a series of scaffolded assignments designed to implement James Lang's four features of mastery, low-stakes assignments, intrinsic motivation, and high expectations of success (Lang, 2013). Two of those assignments: the storyboard and the poster, are the main focus of this study. The specific questions addressed are:

1. Was plagiarism reduced?

2. Could the development of Lang's features be extrapolated from student perceptions of the overall Project?

3. Did students find the storyboard an effective scaffolding tool?

4. Did the students feel that plagiarism was less likely when presenting one's research in the form of a poster, rather than a research paper

\section{Literature Review}

Research shows that defining plagiarism and talking about it in class is one very effective technique for amelioration (Park, 2003; Macdonald \& Carroll, 2006). However, such a technique is most useful when used in concert with institution-wide programs. As such, an in-depth discussion of this aspect of plagiarism is beyond the scope of this paper. For the purposes of this

Journal of the Scholarship of Teaching and Learning, Vol. 18, No. 4, December 2018.

josotl.indiana.edu 
study, plagiarism was defined by the instructor as "using the thoughts, words, ideas, or images someone else thought, wrote, said, published, photographed, or filmed and claiming them for your own. Claiming them can be either explicit ('I wrote this, aren't I brilliant!'), or implicit (I'll just paste this little sentence of Aristotle's into my paragraph — no one will know it's not mine)."

Just as student populations are complex, so, to, is the problem of plagiarism (Park, 2003; Macdonald \& Carroll, 2006; Lang, 2013). In general, the literature on plagiarism surveys complexity through the lens of three broad themes: the philosophical-ethics and definitions (Bugeja, 2001; Chandrasoma, Thompson, \& Pennycook, 2004; Burrus, McGoldrick, \& Schuhmann, 2007); types and perspectives - students, staff, faculty (Roth \& McCabe, 1995; Baldwin, Daugherty, \& Rowley, 1998; Wojitas, 1999; Higbee \& Thomas, 2000); and demographic - geographic location, age, ancestral background, class, extra-curricular clubs and affiliations, etc. (McCabe \& Trevino, 1997; Burnett, 2002). However, Macdonald and Carroll look deep, rather than broad and argue for a "holistic" approach to plagiarism, whereby the agency to thwart plagiarism exists on multiple levels, with multiple stakeholders (2006, p. 236). ${ }^{1}$

That the classroom environment is, in part, what invites students to cheat and is what also can be altered to eliminate the cheating is a well-explored proposal (Howard \& Robillard, 2009; Lang, 2013). Lang builds on current plagiarism research and cognitive theory to distill four features of a learning environment that are conducive to ameliorating cheating: mastery of the material for its own sake, low-stakes assignments, intrinsic motivations for learning and, a high expectation of success (Lang, 2013). A shift in classroom environment could both be predicated upon and success determined by attention to these features and their descriptions.

\section{Four Features of The "Cheat-Free" Learning Environment}

Mastery: Murdock and Anderman (2006) distinguish two types of learners in the classroom-learners who seek to understand and learners who seek to display their ability (p. 130). Lang (2013) dubs the two orientations as "mastery" and "performance"(p. 41). Performers are more likely to cheat because they are motivated by extrinsic reward, for example, pleasing one's parents by achieving a high mark (Lang, 2013). A classroom that "establishes a clear learning objective...gives (students) choices in how they could best meet that learning objective...(and provides) multiple and perhaps even repeated opportunities to do so" will reward mastery over performance (Lang, 2013, p. 88). A classroom that does this will contain fewer cheaters, unlike one that rewards the ability to perform a specific task at a given point in time to a certain level.

Low-Stakes Assignments: Research on cheating shows that high stakes assignments (finals that count for $80 \%$ of one's mark, stand-alone projects or research papers that count for $70 \%$, etc.) are more likely to pressure students to cheat (Amrein \& Berliner, 2002). It has been shown that low-stakes assignments that facilitate (or scaffold) subsequent learning not only discourage cheating but also reduce anxiety over performing and promote mastery (Ambrose, Bridges, Lovett, DiPietro, \& Norman, 2010). Frequency also matters; cognitive science supports the contention that retrieval and rehearsal essentially rewire the brain by increasing the speed and facility whereby students can recall information (Davidson, 2011; Lang, 2013). Coherence between the assignments is also important, transfer of knowledge application from one type of application (say, multiple choice) to another (short-answer) is not automatic (Ambrose, et al., 2010). Therefore, frequent low stakes assignments that are similar in structure and that can be scaffolded to facilitate transfer of knowledge application are invaluable tools for supporting a cheat-free classroom.

\footnotetext{
${ }^{1}$ Note that for the purposes of this paper, "plagiarism" will be used interchangeably with "cheating".
}

Journal of the Scholarship of Teaching and Learning, Vol. 18, No. 4, December 2018.

josotl.indiana.edu 
Intrinsic Motivations for Learning: Provoking intrinsic motivation to tackle a subject for the love of it is sometimes a difficult task. Even if some students are desirous of learning for learning's sake - they often do not feel that they have the luxury of that time. Even so, I knew that I had some students who never missed class, nor an assignment, even in the face of great personal hurdles. Their comments about what motivated and engaged them were much in alignment with what Lang (2013) distills as the three ways to foster intrinsic motivation (p. 65):

- Connecting questions of the course to questions students already have:

- "I am Mexican Catholic and my boyfriend is a Pagan. My family celebrates Dia de Morte and he observes Samhain. I wanted to find out how two cultures in two different parts of the world decided that the dead came back to visit at the same time of the year."

- Challenging students with questions that the instructor can help them see as fascinating or important,

- "I never thought about there being a difference between fear of dying and fear of being dead. I want to think about it more and I can talk about it in Death."

- And, engaging them with authentic (or grounded) assessments. Lang's discussion of grounded assessments supports four particular ways of grounding student's unique experiences: time, place, the personal, and interdisciplinary (2013, p. 77). Time is limited to the confines of any given semester (for example, debating euthanasia at the same time the Canadian Parliament was having the same debate); place is connected to the local community (researching death cafes around town); the personal asks students to reflect on course content and how it might illuminate a personal experience (a friend's suicide, or, as above, cultural differences between themselves and friends/partners); interdisciplinary invites the student to see the connections between one course and others that they are taking or have taken (Quantum physics and string theory and imagining afterlife, for example).

- "When we had to make an advertising campaign for our religion and sell the afterlife, I loved how I could use what I learned in marketing to do work for this class."

- "Having the debate about which was worse-being afraid of dying or being afraid of being dead - was so great - I went home last weekend and told my family about it and we ended up having this really intense discussion at dinner.

A High Expectation of Success: This requires at least two different convictions: that one has the knowledge and/or skills to be successful at a learning task and that one has the confidence that one can apply that knowledge or skill set when called upon to do so. (Murdock \& Anderman, 2006; Lang, 2013). To create an environment conducive to this type of expectation, the course needs to be designed in such a way that the instructor is clear about the knowledge base and skill set that they wish to help the students construct. Scaffolding, combined with a notion of contingent control (Wood, Bruner, \& Ross, 1976) complement this feature by providing a mechanism by which to both promote and assess success.

\section{Scaffolding}

Scaffolding is facilitation by a teacher/tutor/mentor of a skill set or knowledge base that builds upon itself with the mastering of each component. Scaffolding is predicated on socio-cultural theory which, in part, emphasizes context and the intersubjectivity inherent in the process of learning. The key elements of scaffolding include the process of ongoing diagnosis (particularly

Journal of the Scholarship of Teaching and Learning, Vol. 18, No. 4, December 2018.

josotl.indiana.edu 
in terms of determining the learner's Zone of Proximinal Development - the gap between what a learner can know independently and where expert guidance is needed to facilitate advancement of learning), adaptivity, and fading (Vygotsky, 1978; Puntambekar \& Hübscher, 2005). For the purposes of this study, the import of scaffolding lies in its process orientation which dovetails well with Lang's philosophy regarding what works best in combatting plagiarism (Emerson, Rees, \& MacKay, 2005; Murtagh \& Webster, 2010; Lang, 2013).

There are many iterations of scaffolding as educational process (Puntambekar \& Hübscher, 2005). For this study, scaffolding, in concert with contingent control form a methodology that bolsters the framework provided by Lang's four features (Wood, et al., 1976; Lang, 2013). Contingent control provides a regulatory mechanism to support student success (empowering their expectations of success) while scaffolding supports and augments learning, therefore assisting in mastery (Bliss, Askew, \& Macrae, 1996). In this case, scaffolding takes advantage of student "buy in" to the subject matter and, in essence, breaks down the task of the learning into components that are manageable. As a first step, when foundational knowledge is being acquired, the tasks are defined and prescribed, necessitating a restriction in the degree of freedom allowed the student (Bliss, et al., 1996). As the student becomes more adept in marking the critical features of the subject under study, building their skill set and knowledge base, more freedom and leeway for exploration and expression open up. Scaffolding, when it is used appropriately, helps to maintain the direction of the learning and to control possibly debilitating frustration (but not all frustrationsometimes frustration is a handy tool), while at the same time compelling the student to push themselves just a bit more. Contingency control— the regulating component-consists of paying attention and offering an immediate increase in help when failure occurs and then, with each success, offer instructions or information coupled with less and less help. The ideal outcome, of course, is not only mastery of the knowledge base or skill set, but an ease with said tools that allows for their application independent of the teacher/tutor/mentor (Wood, et al, 1976). This supports Lang's features in several ways. First, scaffolding is about mastery-performance is merely one way in which the process of mastery can be measured. Secondly, scaffolding, by definition, works best when implemented as small steps - paralleling Lang's argument for lowstakes assignments. Thirdly, scaffolding reinforces high expectations of success, because the learner has built the skills and knowledge they need for whatever implementation via the scaffolding process. I would argue, as well, that scaffolding can promote intrinsic motivation, but the first three are by far the strongest arguments for the usefulness of scaffolding in this context.

Scaffolding has been used successfully as a pedagogical technique for writing. (Barnard \& Campbell, 2005), but experience had shown me that, even by scaffolding and being mindful of Lang's features, my less confident students might disengage at the very thought of a research paper. By far the most energizing classroom techniques I had tried were implemented by instinct and in reaction to student's reluctance to engage with one another outside of their social comfort zone. I had started to experiment with using visual in-class assignments to bridge cultural and language gaps. Using a collaborative model of informal group pedagogies, we made comics and drew storyboards (Davis \& Shadle, 2000). We did mind-mapping and created advertising campaigns. This, in concert with insisting that groups change composition on a regular basis, proved to be a popular move. The student feedback (both anecdotal, and in end of semester evaluations where they were asked specifically to comment on these assignments) was consistently positive regarding both the engagement and the amount of learning they felt had happened. Since student "buy-in" was an important factor on the road to mastery and intrinsic motivation, I

Journal of the Scholarship of Teaching and Learning, Vol. 18, No. 4, December 2018.

josotl.indiana.edu 
Hale

determined to incorporate these visual assignments into whatever evolution my classroom environment made.

\section{Posters}

It was then that I happened to have a serendipitous conversation with a colleague. We had been discussing the relative merits of a particular academic conference. She shook her head adamantly, "I never go to that conference," she lowered her voice and drew closer, about to reveal a shocking secret, "I hear they actually read their papers!" Her voice got even lower. "Out loud!" Shocking, indeed. She went on to describe the poster sessions that were more common in her discipline. I knew about poster sessions, of course, but at that point, they were not being widely used in the Arts and Humanities. To be sure, at the time they were beginning to gain a foothold at conferences, but were still mostly associated with the Sciences and the Social Sciences.

Jarvis and Cain (2003) describe posters as self-contained visual displays of information that represent an alternative assessable product in projects that typically lead to traditional outcomes such as essays. They can be created either by groups or individuals (Jarvis \& Cain, 2003) Trae Stewart provides an excellent history of the conference academic poster presentation, noting that myriad science and social science disciplines have adopted posters as classroom assessment tools (Dubois, 1985; Stewart, 2008). The literature on poster presentations in the Humanities is not extensive, much of it focused on design and presentation (Dubois, 1985; Roundtree, 2010; McNamara, Larkin, \& Beatson, 2010). Classroom-based research tends to focus on posters as a useful tool for reflection (Stewart, 2008; McNamara, et al., 2010). Stewart (2008) has a comprehensive discussion regarding the pros and cons of posters. The pedagogical usefulness of posters, however, is well-established. For all disciplines, posters develop valuable skills in research and analyses, oral and visual presentation, focus, discrimination and, collaboration (Gipps, 1994; Thorley \& Gregory, 1994; Biggs, 1998; Wimpfheimer, 2004). Most importantly, it has been shown that poster projects reduce plagiarism and, at the very least, facilitate ease of detection (Carroll \& Appleton, 2001; Stefani \& Carroll, 2001; Jarvis \& Cain, 2003) Therefore, in concert with scaffolding and the four features, posters could be another tool for precluding plagiarism. But, the course content had to meet other criteria besides that of thwarting plagiarism.

As with most Art and Humanities courses, there is an institutional expectation that students will emerge with certain fundamental skill sets in the areas of writing, research, critical and creative thinking. My department, also, has expectations of a two-thousand level course, beyond knowledge specific to the discipline. In my context, students should know how to develop and frame research questions, utilize the research librarian and, do basic research - online and in the library. They should also know how to create an annotated bibliography for a research project, and be able to produce a research project - typically a paper. Adding to that, because my preferred pedagogy includes classroom collaboration and peer-to-peer learning, a presentation component is always included in classes that I teach at this level. The project that I was envisioning would make posters and their presentation the culmination of a semester's work which would itself involve scaffolding smaller, low-stakes assignments that would cover the institutional and departmental and personal pedagogical concerns. The project would give the students time to dive deeply into a topic of their choice, facilitating buy-in and intrinsic motivation.

Journal of the Scholarship of Teaching and Learning, Vol. 18, No. 4, December 2018.

josotl.indiana.edu 
Hale

\section{Research Methodology}

\section{Background and Context}

The research was done at a small, public University in Atlantic Canada. The student population represents diversity on a wide scale: nationality, culture, gender, class, sexual orientation, rural and urban, young and mature. Many of them are the first in their family to attend University. Their language skills and academic prowess are equally diverse. The Religious Studies department is small and several of the courses I teach fulfill general Arts requirements for a variety of majors within the University. Thus, my two and three thousand level courses usually have students representing Arts, Sciences, Social Sciences, and Commerce. The Death course has a capacity for seventy students and it is usually full. Because the course is so popular, students sometimes try two or three years to get into it, meaning that, although it is a second year course, I usually have a fair amount of third and fourth year students in any given semester. The preliminary study was conducted in the 2014 and 2015 fall semesters.

\section{Participants, Study Design, and Data Collection}

I constructed a rubric for the crafting of the project components (Tables 1 and 2). The rubrics contained themes relating to Lang's four features and scaffolding and noted whether and how each component might support the theoretical framework.

Table 1. Death Fair Project components and Lang's Four Features of a Cheat-Free Classroom

\begin{tabular}{|c|c|c|c|c|}
\hline & Mastery & Low Stakes & Intrinsic Motivation & $\begin{array}{l}\text { High Expectation } \\
\text { of success }\end{array}$ \\
\hline $\begin{array}{l}\text { Death Fair } \\
\text { Project } \\
\text { Overall }\end{array}$ & $\begin{array}{l}\text { X } \\
* \text { Clear learning objectives } \\
\text { *Process valued over } \\
\text { performance } \\
\text { *Multiple opportunities for } \\
\text { demonstrating skills }\end{array}$ & $\begin{array}{l}\text { X } \\
\text { *Multiple assignments worth } \\
\text { small amount of points } \\
\text { *Similar applications of } \\
\text { knowledge for some } \\
\text { *Assignments scaffolded to } \\
\text { facilitate transfer }\end{array}$ & $\begin{array}{l}\mathrm{X} \\
\text { *Invites questions students } \\
\text { bring } \\
\text { *Sub topics encourage } \\
\text { (to varying degree) time, } \\
\text { place, the personal, } \\
\text { interdisciplinarity }\end{array}$ & $\begin{array}{l}\text { X } \\
\text { *Peer and instructor } \\
\text { evaluation should have } \\
\text { led to a conviction of } \\
\text { skills and knowledge } \\
\text { and confidence in } \\
\text { application }\end{array}$ \\
\hline $\begin{array}{l}\text { Process } \\
\text { Journal }\end{array}$ & $\begin{array}{l}\text { X } \\
\text { *Process more valued than } \\
\text { performance-full marks for } \\
\text { discussing process }\end{array}$ & $\begin{array}{l}\mathrm{X} \\
\text { *Two points per entry } \\
\text { *Frequency }\end{array}$ & $\begin{array}{l}\mathrm{X} \\
* \text { Rationale for initial interest } \\
\text { *Opportunity to see } \\
\text { knowledge and skill set } \\
\text { accumulating }\end{array}$ & $\begin{array}{l}\text { X } \\
{ }^{*} \text { Consistent feedback and } \\
\text { ongoing help }\end{array}$ \\
\hline Proposal & & $\begin{array}{l}\mathrm{X} \\
\text { *Low point value }\end{array}$ & $\begin{array}{l}\text { X } \\
\text { *Forces the development of } \\
\text { questions that deepen initial } \\
\text { interest } \\
\text { *Can also focus student on } \\
\text { time, place, personal, } \\
\text { interdisciplinarity }\end{array}$ & $\begin{array}{l}\mathrm{X} \\
\text { *Clear model } \\
\text { *Opportunity to do it } \\
\text { again and again until it is } \\
\text { right }\end{array}$ \\
\hline $\begin{array}{l}\text { Annotated } \\
\text { Bibliography }\end{array}$ & $\begin{array}{l}\text { X } \\
* \text { Opportunity to demonstrate } \\
\text { research skills } \\
\text { *Opportunity for re-write } \\
\text { emphasizes process }\end{array}$ & $\begin{array}{l}\mathrm{X} \\
\text { *Low point value } \\
\text { *Detailed feedback }\end{array}$ & $\begin{array}{l}\mathrm{X} \\
\text { *Possibility that exposure to } \\
\text { relevant literature will help } \\
\text { deepen interest }\end{array}$ & $\begin{array}{l}\text { X } \\
* \text { Model } \\
\text { *Variety of mode of } \\
\text { instruction and feedback } \\
\text { *Can re-write }\end{array}$ \\
\hline Storyboard & $\begin{array}{l}\text { X } \\
\text { *Demonstrate skills and } \\
\text { knowledge } \\
\text { *On-the-spot feedback allows } \\
\text { for quick revisions- } \\
\text { emphasizing process }\end{array}$ & $\begin{array}{l}\text { X } \\
\text { *Low point value } \\
\text { *Immediate feedback } \\
\text { *Group in-class process }\end{array}$ & $\begin{array}{l}\text { X } \\
\text { *Strengthens interest by } \\
\text { connecting their own } \\
\text { questions and work with } \\
\text { those of their other group } \\
\text { members }\end{array}$ & $\begin{array}{l}\text { X } \\
\text { *Confidence built in } \\
\text { sharing knowledge with } \\
\text { peers in group } \\
\text { *Options for construction } \\
\text { that allow for strengths } \\
\text { to show through }\end{array}$ \\
\hline
\end{tabular}

Journal of the Scholarship of Teaching and Learning, Vol. 18, No. 4, December 2018.

josotl.indiana.edu 
Hale

\begin{tabular}{|l|l|l|l|l|}
\hline Presentation & $\begin{array}{l}\mathrm{X} \\
* \text { Clear rubric }\end{array}$ & & $\begin{array}{l}\mathrm{X} \\
* \text { Exchange of knowledge } \\
\text { and the positive } \\
\text { reinforcement of questions } \\
\text { and research brought about } \\
\text { by interest of peers. }\end{array}$ \\
& $\begin{array}{l}\text { meetings and class } \\
\text { activities and } \\
\text { storyboards } \\
\text { Models of successful } \\
\text { presentations rubric }\end{array}$ \\
\hline Peer Review & $\begin{array}{l}\mathrm{X} \\
\text { longitudinal }\end{array}$ & $\begin{array}{l}\mathrm{X} \\
* \text { Opportunity to participate } \\
\text { meaningfully as an } \\
\text { evaluator }\end{array}$ \\
\hline
\end{tabular}

Table 2. Death Fair Project components and scaffolding criteria

\begin{tabular}{|c|c|c|c|c|c|c|}
\hline & Process Journal & Proposal & $\begin{array}{l}\text { Annotated } \\
\text { Bibliography }\end{array}$ & Storyboard & Presentation & $\begin{array}{l}\text { Peer } \\
\text { Review }\end{array}$ \\
\hline Buy-in & $\begin{array}{l}\mathrm{X} \\
* \text { Explain reason for } \\
\text { choice } \\
\text { *Weekly reflection on } \\
\text { engagement }\end{array}$ & $\begin{array}{l}\mathrm{X} \\
* \text { Engagement } \\
\text { with subtopics }\end{array}$ & & $\begin{array}{l}\text { X } \\
\text { *Seeing sub-topics } \\
\text { come together } \\
\text { demonstrates depth } \\
\text { of topic and import } \\
\text { of individual sub- } \\
\text { topics }\end{array}$ & $\begin{array}{l}\text { X } \\
\text { *Positive } \\
\text { reinforcement by } \\
\text { peers }\end{array}$ & \\
\hline $\begin{array}{l}\text { Reduce } \\
\text { freedom }\end{array}$ & & $\begin{array}{l}\mathrm{X} \\
* \text { Strict form }\end{array}$ & $\begin{array}{l}\mathrm{X} \\
* \text { Strict form }\end{array}$ & & & $\begin{array}{l}\text { X } \\
* \text { Strict } \\
\text { Form }\end{array}$ \\
\hline $\begin{array}{l}\text { Marking } \\
\text { critical } \\
\text { features }\end{array}$ & $\begin{array}{l}\mathrm{X} \\
* \text { Reflection on research } \\
\text { process }\end{array}$ & $\begin{array}{l}\text { X } \\
* \text { Must pay } \\
\text { attention to these } \\
\text { when composing }\end{array}$ & $\begin{array}{l}\text { X } \\
* \text { Involved in } \\
\text { exploring models of } \\
\text { how these are } \\
\text { applied }\end{array}$ & $\begin{array}{l}\text { X } \\
* \text { Must include these } \\
\text { *Become cohesive } \\
\text { factors for sub-topic } \\
\text { comprehension }\end{array}$ & $\begin{array}{l}\text { X } \\
* \text { Must, if to be } \\
\text { successful }\end{array}$ & $\begin{array}{l}\mathrm{X} \\
* \text { Must }\end{array}$ \\
\hline $\begin{array}{l}\text { Maintain } \\
\text { direction }\end{array}$ & $\begin{array}{l}\text { X } \\
* \text { Weekly writing } \\
\text { emphasizes focus }\end{array}$ & $\begin{array}{l}\mathrm{X} \\
* \text { Asks group to } \\
\text { look ahead }\end{array}$ & $\begin{array}{l}\mathrm{X} \\
* \text { Research refines } \\
\text { focus }\end{array}$ & $\begin{array}{l}\text { X } \\
* \text { Putting it all } \\
\text { together shifts focus } \\
\text { into another gear }\end{array}$ & $\begin{array}{l}\text { X } \\
* \text { Must, for } \\
\text { coherence of } \\
\text { materials and } \\
\text { cohesiveness of } \\
\text { group-self } \\
\text { regulated }\end{array}$ & $\begin{array}{l}\mathrm{X} \\
\text { *Focus }\end{array}$ \\
\hline $\begin{array}{l}\text { Frustration } \\
\text { control }\end{array}$ & $\begin{array}{l}\text { X } \\
* \text { Access to help at any } \\
\text { time }\end{array}$ & $\begin{array}{l}\mathrm{X} \\
\text { *Free re-writes }\end{array}$ & & & $\begin{array}{l}\mathrm{X} \\
\text { Freedom of form }\end{array}$ & \\
\hline $\begin{array}{l}\text { Failure }= \\
\text { immediate } \\
\text { help }\end{array}$ & $\begin{array}{l}\text { X } \\
\text { *Instructor monitors } \\
\text { students with problems } \\
\text { more closely }\end{array}$ & $\begin{array}{l}\mathrm{X} \\
* \text { Swift feedback } \\
* \text { Close } \\
\text { monitoring }\end{array}$ & $\begin{array}{l}\text { X } \\
* \text { Swift and } \\
\text { comprehensive } \\
\text { feedback }\end{array}$ & $\begin{array}{l}\text { X } \\
* \text { Immediate } \\
\text { feedback from one } \\
\text { another and from } \\
\text { instructor }\end{array}$ & $\begin{array}{l}\mathrm{X} \\
* \text { Instructor } \\
\text { present as back-up }\end{array}$ & \\
\hline $\begin{array}{l}\text { Success= } \\
\text { less help }\end{array}$ & & $\begin{array}{l}\text { X } \\
* \text { When } \\
\text { component } \\
\text { competently } \\
\text { completed, } \\
\text { instructor waits } \\
\text { until asked to } \\
\text { intervene }\end{array}$ & $\begin{array}{l}\mathrm{X} \\
* \text { Competent } \\
\text { completion proves } \\
\text { readiness for more } \\
\text { autonomy }\end{array}$ & $\begin{array}{l}\mathrm{X} * \text { Comprehensive } \\
\text { end-product proves } \\
\text { readiness for more } \\
\text { autonomy }\end{array}$ & $\begin{array}{l}\mathrm{X} \\
* \text { Satisfaction at } \\
\text { successful } \\
\text { autonomous } \\
\text { presentations }\end{array}$ & $\begin{array}{l}\mathrm{X} \\
* \text { Trust of } \\
\text { Instr. }\end{array}$ \\
\hline
\end{tabular}

For the purposes of this study, data was only collected for the storyboard and presentation portion of the chart (Table 3 ).

Table 3. Death Fair Rubric: Storyboard and Poster Presentation

\begin{tabular}{|c|c|c|c|}
\hline$x$ & & Storyboard & Poster Presentation \\
\hline $\begin{array}{c}\text { Mastery: } \\
1 . \\
\\
2 . \\
3 .\end{array}$ & $\begin{array}{l}\text { Clear Learning } \\
\text { Objective } \\
\text { Choices } \\
\text { Repeat Opportunities }\end{array}$ & $\begin{array}{ll}\mathrm{X} & \\
\text { 1. } & \text { rough model of final product } \\
\text { 2. } & \text { free-hand or digital } \\
\text { 3. } & \text { In-class re-do }\end{array}$ & $\begin{array}{ll}\mathrm{X} & \\
\text { 1. } & \text { Rubric } \\
\text { 2. } & \text { Flexibility in Presentation }\end{array}$ \\
\hline \multicolumn{2}{|c|}{ Low Stakes } & $\mathrm{X}$ & \\
\hline
\end{tabular}

Journal of the Scholarship of Teaching and Learning, Vol. 18, No. 4, December 2018.

josotl.indiana.edu 
Hale

\begin{tabular}{|c|c|c|c|c|}
\hline $\begin{array}{ll}\text { 1. } & \text { Low point value } \\
2 . & \begin{array}{l}\text { Repetition of like } \\
\text { assignments }\end{array}\end{array}$ & & $\begin{array}{ll}\text { 1. } & \text { Low point value } \\
\text { 2. } & \text { Scaffolding to Poster }\end{array}$ & & \\
\hline $\begin{aligned} & \text { Intrinsic } \text { Motivation } \\
& \text { 1. } \text { Questions students care } \\
& \text { about } \\
& \text { 2. } \begin{array}{l}\text { Connections between } \\
\text { course and questions } \\
\text { students bring }\end{array} \\
&\end{aligned}$ & $\mathrm{X}$ & $\begin{array}{l}\text { 1. Reinforces their own questions by } \\
\text { discourse with others in group } \\
\text { 2. Small leap from connecting } \\
\text { individual interests with those of } \\
\text { classmates to those of the course. }\end{array}$ & $\mathrm{X}$ & $\begin{array}{l}\text { 1. Exchange of knowledge and the positive } \\
\text { reinforcement of questions and research } \\
\text { brought about by interest of peers. }\end{array}$ \\
\hline $\begin{array}{ll}\text { High Expectation of Success } \\
\text { 1. } & \begin{array}{l}\text { Confidence in } \\
\text { knowledge }\end{array} \\
\text { 2. } & \begin{array}{l}\text { Confidence in ability to } \\
\text { apply it }\end{array} \\
\end{array}$ & $\mathrm{X}$ & $\begin{array}{l}\text { 1. Confidence built in sharing } \\
\text { knowledge with peers in group } \\
\text { 2. Confidence builds in constructing } \\
\text { coherent whole }\end{array}$ & $\mathrm{X}$ & $\begin{array}{l}\text { 1. Practice via group meetings and class } \\
\text { activities and storyboards } \\
\text { 2. Successful completion of previous } \\
\text { assignments }\end{array}$ \\
\hline $\begin{array}{l}\text { (Scaffolding) } \\
\text { Buy-in }\end{array}$ & $\mathrm{X}$ & $\begin{array}{l}\text { 1. Learning about the subtopics of } \\
\text { others reinforces initial interest and } \\
\text { import of one's own subtopic }\end{array}$ & $\mathrm{X}$ & $\begin{array}{l}\text { 1. Positive reinforcement by peers } \\
\text { 2. Interaction with the presentations of } \\
\text { others }\end{array}$ \\
\hline Reduce freedom & & & & \\
\hline $\begin{array}{l}\text { (Scaffolding) } \\
\text { Marking critical features }\end{array}$ & $\mathrm{X}$ & $\begin{array}{l}\text { 1. Facility with theory and method } \\
\text { built in group setting }\end{array}$ & $\mathrm{X}$ & 1. Must, if poster is to be successful \\
\hline $\begin{array}{l}\text { (Scaffolding) } \\
\text { Maintain direction }\end{array}$ & $\mathrm{X}$ & $\begin{array}{l}\text { Construction of coherent whole } \\
\text { keeps focus and allows } \\
\text { comprehension of bigger focus }\end{array}$ & $\mathrm{X}$ & Must, if presentation is to be successful \\
\hline $\begin{array}{l}\text { (Scaffolding) } \\
\text { Frustration } \\
\text { control }\end{array}$ & & & $\mathrm{X}$ & 1. Freedom of form \\
\hline $\begin{array}{l}\text { (Scaffolding) } \\
\text { Failure=immediate help }\end{array}$ & $\mathrm{X}$ & $\begin{array}{l}\text { 1. Immediate feedback from one } \\
\text { another and from instructor }\end{array}$ & $\mathrm{X}$ & 1. Instructor present as back-up \\
\hline $\begin{array}{l}\text { (Scaffolding) } \\
\text { Success=less help }\end{array}$ & $\bar{X}$ & $\begin{array}{l}\text { 1. Comprehensive end-product proves } \\
\text { readiness for more autonomy }\end{array}$ & $\mathrm{X}$ & $\begin{array}{l}\text { 1. Satisfaction at successful autonomous } \\
\text { presentations }\end{array}$ \\
\hline
\end{tabular}

I chose the presentation component, because the poster was the culmination of the project - a sort of highlight in a process-driven project. The storyboard component was chosen for the preliminary study because it was the most obvious of the scaffolding tools, being done right before the poster fair and linking concretely to the actual poster. As well, whilst the process of growing knowledge was enabled by the other project components, the storyboard necessitated the dissemination and application of that knowledge. As this was a very preliminary study and I was assessing my teaching interventions, I used convenience sampling and an action research methodology (Sagor, 2000; Mills, 2000).

Students were introduced to the Death Fair Project on the first day of classes, although the project does not start until week five, when topics are picked. In the weeks leading up to sign-ups, in-class exercises and assignments were undertaken to help students gain foundational training in Religious Studies. The class session before sign-ups was devoted to a deep description of the project. For thirty minutes there was a powerpoint that covered each component in detail. The powerpoint remained available to students for their reference. Each component was touched upon briefly in this introductory session. Sample slides of storyboards, poster presentations, annotated bibliographies, proposals, and journal entries were discussed and also remained available. Topics were introduced and expanded upon, as were logistics. For the remaining forty-five minutes, the class worked in small groups practicing how to break down a larger topic into sub-topics. The topics they used were not ones available to them for the actual project. They merged with another group to justify and critique and modify their work in preparation for their initial small group meetings with their actual groups and topics.

Journal of the Scholarship of Teaching and Learning, Vol. 18, No. 4, December 2018.

josotl.indiana.edu 
Data was gathered from three different instances: student Process Journals (a compulsory in-class assignment lasting for five weeks); the student comment section on course evaluations; a bonus point opportunity at the end of the semester. One hundred and twenty students participated in the process journal exercise. Out of these, forty made comments that were pertinent to the presentations and the storyboards. There were eighty potential respondents from course evaluations. Out of these, thirty-six made comments directly referencing the presentations and storyboards. There were thirty-six potential respondents to the Bonus Point Opportunity. All thirtysix made comments regarding the storyboard and/or presentations. The process journals enabled me to make immediate changes and adjustments where needed to individual students and groups (Mills, 2000). The end of semester responses inspired changes in ensuing iterations of the courseall of which will be explored in the discussion section. What follows next is an explanation of the project and the tables aligning project components with Lang, scaffolding and contingency factors.

\section{The Death Fair Assignment}

The Death Fair Project (as it eventually became known), is a project-based, collaborative assignment consisting of five components, each designed to scaffold student learning and culminate in a poster session, or Death Fair. The Poster Presentation culminates the Project and takes place on the last three classes but one of the semester. Four groups present per session. This ensures adequate reviewing time at each poster. As well, it allows for students who are not presenting to view the posters and ask questions.

\section{Groups}

For this project, students sign up online for formal learning groups based on their interests. I offer twelve sub-topics to be divided among seventy students, assuring a maximum of six students per group - more than six having been found to be less than optimal (Davies, 2009). Some topics I have offered include: Near Death Experiences Across Cultures; Is the Fear of Death Really Universal?; Zombies, Ghosts, and Vampires: The Undead Among the Living; Histories of Hell; Reincarnation and Resurrection in Doctor Who; Death in Comics; Pet Death; Death and Humour; Death Midwives: Escorting the Dead and; The Work of the Dead: Forensics, Religion, and Death. The topics are purposefully broad, so as to give students adequate leeway to follow their interests and to increase the chances of intrinsic motivation and buy-in (Lang, 2013; Wood, et al., 1976). Students sign up for topics as individuals, rather than forming groups and picking a group topic. This is done in order to take advantage of the effect mutual enthusiasm has in motivating individuals (Murdock and Anderman, 2006). Groups meet together for the first time in class and have a prescribed agenda for this first-time meeting: introductions, discussion and assignment of sub-topics, exchange of contact information, and agreement regarding how to stay in touch. At least two more class sessions are set aside for groups to meet and work together - the final in-class session being a group storyboard of their proposed poster for the Death Fair. I am actively involved during these sessions, spending time with each group.

\section{Components}

The components of the Death Fair Project are laid out in Table 1. The project balances group work with individual work in part to alleviate the concern students have about relying on other group

Journal of the Scholarship of Teaching and Learning, Vol. 18, No. 4, December 2018.

josotl.indiana.edu 
members for their marks and about group members who "ride the coattails" of the hard workers and achieve the same mark, while putting in very little work (Davies, 2009).

For the students, each component is presented to the class in detail as time draws closer to its due date. In the first week of the Project, for instance, the Process Journal is elaborated uponpurpose, logistics, expectations. The first week's questions start on week six and are specific, using the scaffolding technique of reducing student freedom until they have a firm enough grasp of the assignment to feel comfortable "flying solo".

For each component, students are required to focus their energies on reflecting on, researching, and/or refining their topic and sub-topic. Although there is an end-goal in sight (a successful poster presentation), the construction of the project rewards process (and hence, mastery) over performance. The instructor evaluation of each component assesses whether or not the student or group has achieved the level of mastery necessary to be able to build upon their knowledge.

Process Journal (Five Entries, 2 points each): The process journal is designed to facilitate communication between student and instructor as well as to strengthen writing and reflections skills (Etkina \& Andre, 2002). The process journal is exactly that, a journal of the students' learning process over the course of the project. They are due by five o'clock each Friday (special arrangements are sometimes made for students who have timing conflicts due to outside commitments) Week One has a prescribed question: "Why did you choose this topic? What about it intrigues you? What ideas do you have at this point about how you would like to address it?" Weeks Two through Five ask the student to: "describe the work you are doing; describe the way you are going about you research; discuss the thoughts and questions that your research has raised." In addition, the process journal is a private space wherein group members can discuss how their group is working and whether or not they are having trouble with any aspect of the Project.

Proposal (10 points): The Proposal is designed to help the group as a whole focus on how they want to subdivide their topic and how they plan to fit those subtopics together. It encourages teamwork and facilitates skill with big picture and detailed thinking (Davies, 2009). The Proposal is a two to three page document generated by the group and it has a very rigid instructions. It is to contain the name of the group and the group members. The group must generate a focus or thesis for their general topic (i.e. Body Disposal may choose to look at the ways in which different cultures dispose of their dead, choose to look at a variety of religious worldviews, or might look at the topic historically in one or two cultures). Each group member named must be assigned a subtopic (i.e. Ancient Egypt, medieval Persia, $21^{\text {st }}$ century Canada) and a thesis for each subtopic must be named and explained. The proposal also must spell out which group members will be responsible for which administrative tasks (setting meeting times, purchasing materials, etc.). The proposal also must contain a timeline for completion and a brief discussion/drawing of how the group might lay out and present their research.

Annotated Bibliography (10 points): Several studies have been done establishing an annotated bibliography as a useful tool for scaffolding (Bordonaro \& Richardson, 2004; Coulson \& Harvey, 2013). The annotated bibliography is an individual assignment. Students are told that the purpose of the assignment is to help them develop a foundation for their research and to allow the instructor to assist them in finding further resources. In terms of structure, the bibliography must have at least three academic sources and one non-academic source. Sources must, with some exceptions, be dated after the year 2000. The annotations are to be both descriptive and critical. To support students in this endeavor, a librarian comes to class to discuss how to conduct research at the University level. As well as a relevant sample from the instructor on the slides, the slides

Journal of the Scholarship of Teaching and Learning, Vol. 18, No. 4, December 2018.

josotl.indiana.edu 
also provide links to the University library explanation and examples of annotated bibliographies. Examples of $\mathrm{A}+$ bibliographies from previous years are also supplied. Students are given a deliberately broad description of what the instructor is looking for: the annotated bibliography should show their research and analytical skills and their familiarity with the subject. The rubric for marking is also fairly broad:

- Correct number of sources 1

- Correct types of sources 1

- Content (including style) 8

Story Board (10 points): The storyboard is an in-class group assignment done two to three class sessions before the Death Fair. Students must be present in order to get credit for the storyboard. Using presentation-sized Post-It paper and markers or an online storyboard generator, groups create a rough draft of their final poster. Saye and Brush (2002) assert that using storyboards can assist in helping group presentations gain depth and encourage critical reasoning. In addition, this assignment allows students to get a visual representation of their research whilst conveying their findings to the group. The visual aspect is important in that it affords the entire group a concrete example of their individual conceptions regarding the final product. Often students find that what they thought they were conveying clearly to their peers was not at all what was being heard. I visit each group, offering direction, evaluating, and answering questions.

The Storyboard is evaluated with these criteria:

- Content is substantive, reveals solid research, proper citations are used.

- Text is readable; informative without being too wordy.

- Information is presented in such a way as to invite questions.

- Visuals are interesting and serve a purpose; they are used to enhance viewer's knowledge; they are not distracting, but make logical sense in terms of how the poster flows.

- Subtopics are placed in a logical order that allows the viewer to understand how the sub-topics together enhance comprehension of the larger topic.

Poster Presentation (10 points): The Death Fair itself takes place over three class periods, four groups presenting per session. Students are given a plethora of online reference materials for poster design and presentation. There is also an in-class question and answer session. Students are asked to not prepare formal speeches (although some invariably do), but to be prepared to answer questions based on the research they have chosen to highlight on their posters. This is done for the sake of brevity, but also for the instructor to gauge the depth of knowledge each student had acquired. Citations are to be on the body of the poster in the case of direct quotes and a bibliography is to be attached to the back.

Posters are assessed using a rubric (see Appendix 2) that evaluates aesthetics and content (Jarvis \& Cain, 2003; McNamara, et al., 2010). Students are given the rubric in advance and practice with it during the class storyboarding session.

Peer Review (2@5 points each): The peer review for the Death Fair project is divided into two sections: group/self-evaluation and peer review of group posters. Although there is some concern about group cohesion being undermined by them, peer evaluations of groups are important for many reasons, not the least of which is enhancing the perception of fairness in marking (Davies, 2009; Cheng \& Warren, 2000; Oakley, 2002). To ameliorate some of the potential for undermining, group members are asked every week in their Process Journals to comment on how their group is performing. I also do a formal end-of semester peer-evaluation where each member evaluates themselves and their group members (Appendix 3). These evaluations are individual and

Journal of the Scholarship of Teaching and Learning, Vol. 18, No. 4, December 2018.

josotl.indiana.edu 
private and include a self-evaluation as well (Sharp, 2006). Students are required to justify their responses. Evaluations that do not contain explanations beyond "S/he was nice and came to all the meetings" or "So and so was lazy" are set aside.

Peer review of posters is not calculated into the final presentation mark (Sharp, 2006). Students use the same rubric as the instructor and turn their evaluations in at the end of the poster session. While there are good arguments for either anonymous or named reviews, in this instance, reviews are not anonymous, this forces accountability but also allows for deeper assessment of individual learning (Jarvis \& Cain, 2003; Stewart, 2008).

\section{Data Analysis}

My own notes and records for previous years showed that plagiarism was reduced in the semesters where the Death Fair project was implemented instead of a major research paper. I collected posters and each was read closely and references checked in much the same way that a research paper would have been. In this instance, the process journal serves the additional purpose of familiarizing me with individual student voices and facility with written English. It is important to note that my department does not utilize plagiarism software. During the in-class component - the storyboard-instructor notes were also taken for purposes of analysis and comparison with the final poster. Student responses were evaluated inductively: responses to the open-ended questions in Process Journals, Evaluations, and Bonus Points Opportunities were compared with the rubrics constructed (Table 3) to ascertain if themes emerged that supported or negated the use of scaffolding and Lang's features as tools for ameliorating plagiarism.

\section{Results and Discussion}

This section considers each of the aforementioned research questions individually. The questions being researched were:

1. Was plagiarism reduced?

2. Did students find the storyboard an effective scaffolding tool?

3. Did the students feel that plagiarism was less likely when presenting one's research in the form of a poster, rather than a research paper.

4. Could the development of Lang's features be extrapolated from student perceptions of the overall Project?

Was plagiarism reduced? General reflections from the implementation of the Death Fair Projects reveal that plagiarism was reduced both in the annotated bibliography and in the final presentation - the two components that would be most likely to contain plagiarized materials. Plagiarism was never particularly egregious in annotated bibliographies for this course, but before the Death Fair Project, there were three to four instances each semester. The numbers since instituting the Death Fair Project are one to two out of seventy students. The final project, poster presentations as opposed to research papers, also revealed a satisfactory result, with only one to two students having been found to have plagiarized their material (direct cut and paste without any citations as to its original author or context).

Did students find the storyboard an effective scaffolding tool? The in-class storyboard assignment evidenced not only enjoyment, but focused group engagement. Models from previous semesters had been posted around the classroom and there was a slide showing a model from a web-based storyboard generator (Storyboard That!). The conversations heard were markedly

Journal of the Scholarship of Teaching and Learning, Vol. 18, No. 4, December 2018.

josotl.indiana.edu 
different from those heard during the first in-class group meetings. In those first meetings, students had only passing acquaintance with their topics. With two weeks to go until the poster presentations, the conversations were revolving mostly around the ways in which the sub-topics fit together - philosophically as well as visually (a criteria marker for Mastery). Not only did the students get on-the-spot feedback, allowing them to modify their storyboards before turning them in, but students seemed to feel comfortable with what was expected. From an instruction perspective, it was easy to see, from the visual representations, what information was missing or where comprehension was lacking — in either theory, method, or information — feedback was much easier to give.

The criteria laid out under scaffolding has been enumerated in the features discussion. Buyin, marking critical features, maintaining direction, frustration control and the benefits of immediate feedback and supervision leading to the eventual successful "launching" of students for poster presentations are embedded in student comments regarding the benefits of group work on their facility with and understanding of sub-topics as they relate to the topics and then again to the course as a whole. In these student responses, an explicit mention of the function of the storyboard as scaffolding was mentioned only twice.

Two scaffolding criteria that were not mentioned or referred to are: the instructor being available as back-up during the presentation and freedom of form as a tool for curtailing frustration. Since the instructor was evaluating during the poster presentations, it is reasonable for students not to perceive that I was also available to help them if they ran into problems. In reality, I (and my TA) were highly conscious of the classroom atmosphere and more than once quietly drifted over to a poster that seemed to be generating discussions that had the potential of being more than lively. In terms of frustration, it was not the form of the posters, but the logistics of group work that ended up being the flashpoint for any frustration.

General responses from the students were positive and yielded some intriguing points. Four students did not like the storyboard component, two each from two separate groups: from the one group, a respondent wrote that it "wasn't what we expected and we came in planning to do our poster and then ended up changing it to the (digital) one you put up."; another wrote that "I just don't learn much from visual exercises, but I can see how it's helpful for others."; the third and fourth were in a group together and found that their topic was "too scientific" to be engaged in creatively. It should be noted that the other members of each respective group had a positive response to the exercise. Only two students were adamantly opposed to poster presentations in general, "I could have written three, twelve page papers in the amount of time I had to spend on tracking down my group members and going to meetings!" The other stated that the project "felt like junior high, isn't this supposed to be University?" Other students reported that they had not seen the point of doing the storyboard assignment until they got started and realized that their groups had not really been on the same page in terms of how the research would be presented. The storyboard exercise helped with cohesion. Other comments made mention of the fact that working in groups was highly beneficial because they were learning from one another, bouncing ideas off of each other, and "getting out of my bubble, where only my own ideas are bouncing around."

Most responses indicate that the storyboarding exercise was successful in facilitating understanding of one another's subtopics. Most of these responses also indicated that it was the visual exercise in the context of group work that made the assignment successful.

"What I liked about the story board was that I could visually see how the other things we did built up to it (the storyboard)."

Journal of the Scholarship of Teaching and Learning, Vol. 18, No. 4, December 2018.

josotl.indiana.edu 
Did the students feel that plagiarism was less likely when presenting one's research in the form of a poster, rather than a research paper? In terms of plagiarism, ten students stated that they believed it was easier to cheat on posters than on research papers. Lack of citation apparatus (although bibliographies were required to be on the backs of the posters and all direct quotes cited properly), brevity of text (providing too little contrast to catch a change in writing style), ease of paraphrasing the words of others, the ability to think fast and talk on one's feet (light on substance, big on style), were all touched upon as rationale for posters being easy to plagiarize.

Others were not so sure, pointing to the need to give a substantive presentation of your poster requiring a level of understanding that was difficult, if not impossible, to fake: "...there wasn't a scope for us to cheat, and it was set up in such a way we'd have to present and know what we're talking about, so cheating wouldn't be as simple." Students also cited citation apparatus (given in class and on all subsequent handouts and posts), brevity of text (difficulty in finding quotes that are brief enough and dense enough), the difficulty of paraphrasing the words of others, Perhaps one of the most intriguing things to emerge was the assumption of at least six of the respondents that posters would be easier to plagiarize because professors would have no way to check them against plagiarizing detection software or Google - as if that was the only sure way to determine if a text had been plagiarized. It would be interesting to find out how widespread this assumption is that electronic sources are the only detection tools professors possess to detect plagiarism.

Could the development of Lang's features be extrapolated from student perceptions of the overall project? Mastery: Building mastery requires clear learning objectives, the student having different ways of achieving those objectives, and repeat opportunities to achieve those objectives. Each component had its own objectives, but the rubric, for the storyboard and poster, was used to discern whether or not students saw the storyboard as another opportunity to build their knowledge base by having to explain their subtopics to their group-to discover their own level of mastery by being able to teach what they had learned. As well, groups would receive immediate feedback and have multiple opportunities to re-do the assignment (within the class session). Students did not comment on the options for manual or digital storyboarding. For categories one and three, Student responses aligned in part with the expectations of the rubric:

"The storyboard was a smart idea for linking our work which lead (sp) to understanding things I did not research..."

"The story board was helpful for the poster because it was a way to display our ideas and thoughts about the presentation and get feedback...that way we could determine if our research and thought processes were on the right track."

"I found the use of story boarding and the posters to be a better and more hands-on way to understand the concepts of the topic and explain them to people."

"I think using visual assignments is very helpful because it helps put our ideas onto a canvas, which is specially(sp) crucial to someone who cannot express their project of thoughts into words."

For the poster, students responded as expected on the first criteria, but there were no responses that mentioned the second criteria of flexibility:

Journal of the Scholarship of Teaching and Learning, Vol. 18, No. 4, December 2018.

josotl.indiana.edu 
"Having the rubric posted made it easier to know what was expected"

"I felt good about our ideas, but I was worried about how to present them. The rubric helped keep us on track."

Not mentioning the two options for the storyboard nor the flexibility of the poster presentation could mean that students did not experience the poster as flexible or see an appreciable distinction between digital or manual forms of storyboarding.

Low Stakes: Although it was also low in point values, the poster presentation was not expected to be seen by students as low-stake since it was the culmination of all the assignments. In terms of the storyboard, students gave no mention of the low point value, but many did comment on how they used the poster as a rough draft. Whereas in mastery the concept of repetition was used to discern student's perception of mastery through the ability to share their subtopic cogently with their group, for this category repetition referred more to the idea of a rough draft.

"The storyboard was in reality a rough draft for our poster that allowed us to identify the weaker parts of our project and improve upon these before submitting the final poster board."

"I thought that the storyboard assignment was very helpful. It gave us a chance to really frame out what we would be putting on the poster."

“...it gave us a good idea of how much information we were missing or needed to include/not include."

Students also mentioned that they enjoyed the informal atmosphere of the classroom during the assignment, commenting that it felt, "more like a workshop than a classroom". It is possible that the atmosphere of the session itself contributed to an implicit low stakes "feel" to the assignment.

Intrinsic Motivation: Intrinsic motivation was in evidence as shown by the questions being discussed (the staunchly Roman Catholic student and the atheist earnestly engaging one another in a very civil, knowledgeable conversation about the atheist's Aunt, currently in the Netherlands for Physician Assisted Suicide) and the ways in which the group members shared what their subtopic brought to engagements with those questions. There was a generally high expectation of success. Speculation was that intrinsic motivation would be enhanced in the storyboard component by interaction with other group members. Because students were expected to incorporate course materials (theory, method, questions foundational to Religious Studies) the expectation was that group discussions would touch not only on sub-topics in context of the larger topic, but with broader questions of the course as a whole. While student comments did not, on the whole, directly and clearly match the criteria posited in the rubric, many responses indicated that the collaboration of the storyboard and the interaction of the presentation sustained and added to their enthusiasm for their subtopics:

“...it is possible to learn from other people's ideas, have them build on your own, and better work can be created from it..."

Journal of the Scholarship of Teaching and Learning, Vol. 18, No. 4, December 2018.

josotl.indiana.edu 
Hale

"If we were required to cover an entire topic individually in a research paper, for example, I do not think we would have as much of a thorough understanding of the subject or gained as much from it... whenever our group would come together and we would share our findings...I felt as though I was continually learning throughout the span of this project..."

"For me, I've enjoyed doing it because it is more than working on a project, it also helped me to try answer some important questions of our life and the meaning of our life."

"I think the use of visual assignments facilitated the understanding of the topics because while we did these kinds of assignments, we focused on relating ideas, and connecting points to look at the bigger picture."

"I liked being able to go more deeply into a topic that I got to choose. I was already interested in Euthanasia and this gave me a chance to study it more and to talk to other people about it."

"The poster presentations were great! I learned so much about other people's topics and everyone was so excited to show what they had found out."

In general, student comments were in favour of being able to choose their own topic. This supports a link between agency over topic choice and intrinsic motivation. Students who waited too long to sign up and had to be assigned groups took longer to be engaged. In this instance, the enthusiasm of the other group members enabled productive engagement:

"...to be honest, this was not my choice of topics and I thought it would be really boring. But my group members were into it and their suggestions made me be more positive."

One other group was made up entirely of students who were assigned the topic and the results were not as successful:

"No one knew how to research this (Near Death Experiences), even when you told us where to look, I didn't find anything that would make an interesting sub-topic."

"My group was not into this at all and it made it hard to motivate them, even when I was totally getting great stuff from the librarian, when I'd bring it to meetings, they brought me down."

From the above analysis, a cautious conclusion can be drawn that initiating and supporting intrinsic motivation in the classroom might be most successful when combining student choice (addressing questions the student brings to the classroom) and group work (allowing for collaboration to fuel not only interest, but perhaps the desire to return support in kind to one's colleagues). 
High Expectation of Success: Much of what is relevant in this section has already been reported. Students felt, in general, that the sub-topic research they brought to the storyboard assignment was affirmed and enhanced in collaboration with the work of their group members and that the storyboard gave them visual proof of their competence. Instructor confirmation of that competence was also cited as confidence-building-even when that initial assessment was negative. Students mentioned that the assignments they did in the build-up to the poster presentations (journals, proposals, annotated bibliographies) were also helpful in instilling confidence in knowledge and skill. ("I wish I had done more work on my bibliography, I feel like everyone else in my group is more prepared than me.") Several mentioned that an activity unrelated to the DFP (a marketing campaign for ancient beliefs of the afterlife) had also been helpful in preparing for the presentation. A review of process journal comments reveals that most students felt confident and excited to show their work off to the rest of the class:

"We spent our last meeting tweaking the poster from your suggestions on our storyboard. I am excited to see what everyone thinks!"

"I had my roommate quiz me with questions my group thought we'd be asked so I'd be prepared-I was amazed at how ready I feel!"

"We didn't need the storyboard, we had already figured things out. But, it was nice to have feedback that told us we'd done things right. We're all more relaxed to present, now."

This feature was the one in which student comments connected most clearly with the scaffolding criteria.

\section{All Four Questions Considered}

Lang asserts that classroom environment is a significant factor in academic cheating at the University level (2013). He argues further that four features: mastery, intrinsic motivation, high expectation of success, and low stakes assignments assist in creating a classroom environment less conducive to student cheating. Lang's insights informed the construction of this assignment and the preliminary study. In this case, scaffolded visual assignments were designed to elicit Lang's four features in my Religious Studies "Death" course. The study has several implications. For Humanities classrooms, in particular, introduction of visual assignments more common in the Social Sciences could prove beneficial for student engagement and amelioration of plagiarism. For all University classrooms, this study indicates that assignments designed to elicit Lang's four features could prove to be useful tools in plagiarism reduction.

\section{Limitations to the Study}

- Selection bias. Since the sample was self-selected and, consequentially, done using a nonprobability method, it is possible that my findings will not be reproducible by others.

- Data collection. There were no face to face interviews done for this study and relying only on student's written responses could limit the potential for a richer, and more varied data set. 
- Question design. It is possible that more pointed questions would have elicited a richer data set. My purpose at this juncture was to gather data to enable nimble shifts in pedagogical method and design in addition to gathering data for this preliminary work. As such, I wanted to be as non-directive as possible.

\section{Conclusion}

This was a preliminary study to determine whether or not the Death Fair Project might lead to decreased plagiarism in my classroom and, if so, were the four features Lang asserts (mastery, low stakes, intrinsic motivation, and high expectations of success) discernable as assisting in effecting this decrease. I was also curious to see if using a visual, collaborative in-class assignment, might be an important scaffolding tool for the Project. Lastly, I wanted to see if students perceived posters as being less conducive to plagiarism than research papers. I was looking for qualitative data that could be used to develop a more elaborate and longitudinal project to determine the efficacy of the factors laid out in the research questions:

1. Was plagiarism reduced?

2. Could the development of Lang's features be extrapolated from student perceptions of the overall Project?

3. Did students find the storyboard an effective scaffolding tool?

4. Did the students feel that plagiarism was less likely when presenting one's research in the form of a poster, rather than a research paper

One very interesting detail emerged consistently, confirming what a great deal of literature on plagiarism has stated, that plagiarism has much to do with definition and perception. Students were almost evenly split in whether or not plagiarism was usually a deliberate attempt to trick the professor or an innocent accident ("I heard people bragging about cutting and pasting for their posters" as opposed to "you do so much research, sometimes it is difficult to know what is your idea and what you've read." $)^{2}$ As well, it was apparent from quite a few student comments that, for some, appropriating the work of one's group members constituted plagiarism and was spoken of in terms much more derogatory than those used for plagiarism of scholarly sources. This was an unexpected outcome that supports the contention that, even if a concurrent conversation is not being had with the institution, spending classroom time discussing and defining plagiarism is a worthwhile, and perhaps ameliorating, exercise.

This preliminary study shows evidence that suggests the design and implementation of an assignment such as the Death Fair Project that incorporates group work with small, low-stakes assignments - some of them visual - that are scaffolded to culminate in a poster presentation can be effective in decreasing plagiarism. As well, it is reasonable to postulate that designing such a project to facilitate Lang's four features does assist in creating a classroom atmosphere that empowers students not to engage in cheating.

A complementary aspect of the study reinforces the already extensive literature on the importance of collaboration and group work in not only enhancing student learning, but in building confidence in their ability to apply the knowledge they have gained. Students were almost universal in their enjoyment of the project, many stating that they had learned more in this course than in many others they had taken in University.

\footnotetext{
2 That project was marked by my TA, even before these surveys were read, and were dealt with accordingly. I reported as
} much to the student who had made this observation.

Journal of the Scholarship of Teaching and Learning, Vol. 18, No. 4, December 2018.

josotl.indiana.edu 
The visual aspect of the project was an important component, students not only enjoyed it, but commented on how posters made the dissemination of their own research more challenging and more exacting in its requirements for displaying mastery. Students were surprised at how helpful they found the storyboarding assignment, but preliminary data show that is was a very successful scaffolding tool. By highlighting this, the study supports the current literature on poster presentations as positive assessment strategies in the Arts and Humanities in addition to supporting their inclusion in a campaign to thwart plagiarism.

Using posters and visual assignments requires instructors to invest initial time and effort in developing the skill set necessary for composing posters for the Arts and Humanities. It is also vital to develop a rubric for evaluation that is comprehensive. Once acquired, the time saved in not chasing down plagiarism, combined with the positive feedback and depth of student engagement more than compensate for the initial investment.

\section{Future Work}

The next phase of this study will be to attempt to determine the depth of the relationship between Lang's four features, visual assignments, and any amelioration of plagiarism. There are plans already to add student interviews (done by a neutral third party) to the data set. In addition, I will make the Death Fair Project optional, offering students the opportunity to do a collaborative research paper instead of a poster. Another avenue of research opened up by student responses and my own experiences is that of the use of visual assignments in facilitating substantive crosscultural conversation and learning. Such facilitation could not only further deeper learning for all students, but could also lead to decreased anxiety and stress (and therefore less pressure to plagiarize) on the part of ESL students.

\section{Appendix}

Appendix 1: Questions

Process Journal Questions:

Week One:

Why did you choose this topic?

What about it intrigues you?

What ideas do you have at this point about how you would like to address it?

Weeks Two through Five:

Describe the work you are doing;

Describe the way you are going about you research;

Discuss the thoughts and questions that your research has raised

Please discuss any praise or concern you have regarding your group.

End-of-Semester Evaluation (Anonymous)

Please tell me about your experience with the Death Fair Project.

End-of-Semester Bonus Points Opportunity

Journal of the Scholarship of Teaching and Learning, Vol. 18, No. 4, December 2018.

josotl.indiana.edu 
Hale

1. Setting aside the logistical issues of doing group work, compare and contrast the experience of doing a poster presentation with that of writing a formal, 10-12 page research paper. (1.5 points)

2. Talk (write!) about the use of visual assignments (storyboard, mind-mapping, posters) in this course: in what way were they helpful or not helpful? If you were in groups that were multi-cultural, did the use of pictures/art/symbols facilitate communication across any cultural or linguistic barriers? (1.5 points)

3. This calls for speculation on your part, but I'm very interested in plagiarism: what is more stressful to you? A poster presentation or a research essay? (again, setting aside the group work logistics and potential conflict). Would it be easier to cheat on a poster (even one done individually) or on a research essay? (1 point)

\section{Appendix 2. Rubric used by instructor and students to assess posters during Death Fair.}

\begin{tabular}{|c|c|c|c|}
\hline $\begin{array}{c}\text { 屯 } \\
\text { CATEGORY }\end{array}$ & Exemplary $1 \mathrm{pt}$ & Proficient $.63-.79 \mathrm{pt}$ & Unsatisfactory $.5-.62 \mathrm{pt}$ \\
\hline 1. Graphics & $\begin{array}{l}\text { Graphics used appropriately; greatly } \\
\text { enhance the topic and aid in } \\
\text { comprehension; are clear, crisp and } \\
\text { well situated on the page. }\end{array}$ & $\begin{array}{l}\text { Graphics used appropriately most of } \\
\text { the time; most graphics selected } \\
\text { enhance the topic, are of good quality, } \\
\text { and are situated in logical places on the } \\
\text { page. }\end{array}$ & $\begin{array}{l}\text { Graphics used inappropriately and excessively; } \\
\text { graphics poorly selected and don't enhance the topic; } \\
\text { some graphics are blurry and ill-placed. }\end{array}$ \\
\hline 2. Text & $\begin{array}{l}\text { Easy to read/ appropriately sized; no } \\
\text { more than three different fonts; } \\
\text { amount of text is appropriate for } \\
\text { intended audience; boldface used for } \\
\text { emphasis. }\end{array}$ & $\begin{array}{l}\text { Most text is easy to read; uses no more } \\
\text { than four different fonts; amount of } \\
\text { text generally fits intended audience. }\end{array}$ & $\begin{array}{l}\text { Font too small to read easily; more than four } \\
\text { different fonts used; text amount is excessive for } \\
\text { intended audience. }\end{array}$ \\
\hline 3. Overall Design & $\begin{array}{l}\text { Main concept easily identified; } \\
\text { subtopics branch appropriately from } \\
\text { main idea. Clean design; high visual } \\
\text { appeal; four or fewer symbol shapes; } \\
\text { color used effectively for emphasis. }\end{array}$ & $\begin{array}{l}\text { Main concept easily identified; most } \\
\text { subtopics branch from main idea. } \\
\text { Design is fairly clean, with a few } \\
\text { exceptions; diagrams have visual } \\
\text { appeal; four or fewer symbol shapes; } \\
\text { uses color effectively most of time. }\end{array}$ & $\begin{array}{l}\text { Main concept not clearly identified; subtopics don't } \\
\text { consistently branch from main idea. Cluttered } \\
\text { design; low in visual appeal; diagrams and choice of } \\
\text { colors lacks visual appeal and impedes } \\
\text { comprehension. }\end{array}$ \\
\hline 4. Content & $\begin{array}{l}\text { Reflects essential information; is } \\
\text { logically arranged; concepts } \\
\text { succinctly presented; no misspellings } \\
\text { or grammatical errors; proper } \\
\text { bibliography }\end{array}$ & $\begin{array}{l}\text { Reflects most of the essential } \\
\text { information; is generally logically } \\
\text { arranged; concepts presented without } \\
\text { too many excess words; fewer than } \\
\text { three misspellings or grammatical } \\
\text { errors; sparse bibliography }\end{array}$ & $\begin{array}{l}\text { Contains extraneous information; is not logically } \\
\text { arranged; contains numerous spelling and } \\
\text { grammatical errors. No bibliograpy }\end{array}$ \\
\hline 5. Presentation & $\begin{array}{l}\text { Presenters are knowledgeable and } \\
\text { prepared. They make eye contact and } \\
\text { use the poster as a guide, rather than } \\
\text { reading from it. They are able to field } \\
\text { questions and give information } \\
\text { beyond the information on the poster. } \\
\text { The entire group seems to have a } \\
\text { good grasp of one another's sub- } \\
\text { topics }\end{array}$ & $\begin{array}{l}\text { Presenters are adequately } \\
\text { knowledgeable and prepared. They } \\
\text { make some eye contact. They } \\
\text { occasionally read from the poster rather } \\
\text { than using it as a guide for talking } \\
\text { points. They are reasonably able to ask } \\
\text { questions but give little information } \\
\text { beyond what is on the poster. Some } \\
\text { group members seem to be unclear } \\
\text { about the work of their fellow } \\
\text { collaborators. }\end{array}$ & $\begin{array}{l}\text { Presenters are neither knowledgeable nor prepared. } \\
\text { They seem disengaged with the subject. They make } \\
\text { little eye contact and read the poster to you. They are } \\
\text { unable or unwilling to answer questions. The group } \\
\text { members are not at all knowledgeable about the work } \\
\text { of their fellow collaborators }\end{array}$ \\
\hline
\end{tabular}

Journal of the Scholarship of Teaching and Learning, Vol. 18, No. 4, December 2018.

josotl.indiana.edu 
Hale

Appendix 3. Peer review rubric used by students for self and group evaluation.

Group Name:

Your Name:

- Using the rubric below, rate your group members and yourself for each category.

- Be honest. Please complete your forms on your own. Do not "grade-fix" with other group members.

- If you give everyone a 1 in all or most categories, you MUST justify this with specific and concrete examples.

\section{Performance Scale:}

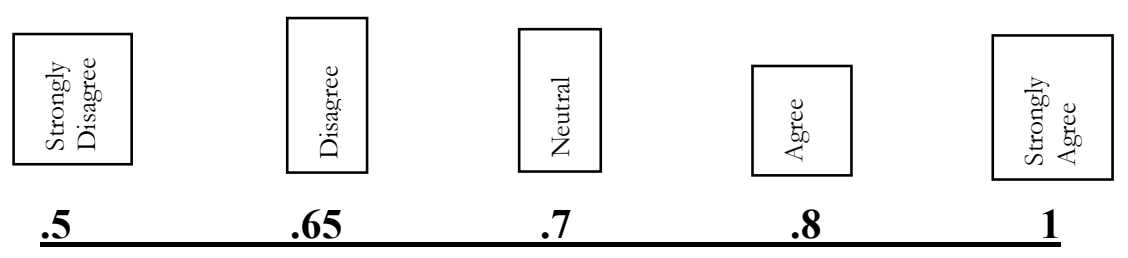

\section{$\underline{\text { Performance Areas \& Definitions }}$}

Attendance: Group member was present for group meetings, Internet chats, or other scheduled meetings/conversations for working on the project.

Punctuality: Group member arrived at scheduled meetings on time; met project deadlines.

Quality of Work: Group member's assigned pieces were complete, thorough, covered the topic well, and were accurate in terms of content (e.g., work did not need multiple revisions or rewrites to improve the quality)

Quantity of Work: Group member took responsibility for completing integral portions of the project (which may have required more time to complete or consisted of a greater percentage of the total project relative to other group members)

Interpersonal Relations: Group member positively contributed to group performance (e.g., helped group move ahead, constructively resolved conflicts, was not destructive to group functioning, etc.)

\begin{tabular}{|l|l|l|l|l|l|l|}
\hline Name & Attendance & Punctuality & Quality & Quantity & Interpersonal & Total \\
\hline & & & & & & \\
\hline & & & & & & \\
\hline & & & & & & \\
\hline & & & & & & \\
\hline & & & & & & \\
\hline
\end{tabular}

If you gave everyone in your group mostly 1's in all categories, please justify your response with specific and concrete examples.

Journal of the Scholarship of Teaching and Learning, Vol. 18, No. 4, December 2018.

josotl.indiana.edu 


\section{References}

Ambrose, S., Bridges, M., Lovett, M., DiPietro, M., \& Norman, M. (2010). How learning works: 7 research-based principles for smart teaching. San Francisco: Jossey Bass.

Amrein, A., \& Berliner, D. (2002). High-Stakes Testing \& Student Learning. Education Policy Analysis Archives, 10, 18. http://dx.doi.org/10.14507/epaa.v10n18.2002

Baldwin, D., Daugherty, S., \& Rowley, B. (1998). Unethical and unprofessional conduct observed by residents during their first year of training. Academic Medicine, 73(11), 1195-1200.

Barnard, R., \& Campbell, L. (2005) Sociocultural theory and the teaching of process writing: The scaffolding of learning in a university context. The TESOLANZ Journal, 13, 76-88.

Biggs, J. (1999). Teaching for quality learning at university: What the student does. Buckingham: Open University Press.

Bliss, J., Askew, M., \& Macrae, S. (1996). Effective teaching and learning: scaffolding revisited. Oxford Review of Education, 22, 37-61.

Bordonaro, K., \& Richardson, G. (2004). Scaffolding and reflection in course-integrated library instruction. The Journal of Academic Librarianship, 30(5), 391-401.

Bugeja, M. (2001). Collegiate copycats. Editor and Publisher, 134(46), 22.

Burnett, S. (2002). Dishonor and distrust. Community College Week, 7(1), 6-8. https://doi.org/10.1177/1469787406061150

Burrus, R. T., McGoldrick, K. M., \& Schuhmann, P. W. (2007). Self-reports of student cheating: Does a definition of cheating matter? Research in Economic Education, 38(1), 3-16.

Carroll, J., \& Appleton, J. (2001). Plagiarism: a good practice guide. Retrieved from http//www.jiscpas.ac.uk/pro/plex?DO=NEWSLETTER\&WAY=DOWNLOAD\&ID=61 .

Chandrasoma, R., Thompson, C., \& Pennycook, A. (2004). Beyond plagiarism: Transgressive and nontransgressive intertexuality. Journal of Language, Identity \& Education, 3(3), 171-193.

Cheng, W., \& Warren, M. (2000). Making a difference: Using peers to assess individual students' contributions to a group project. Teaching in Higher Education, 5(2), 243-256. http://dx.doi.org/10.1080/135625100114885.

Coulson, D., \& Harvey, M. (2013). Scaffolding student reflection for experience-based learning: a framework. Teaching in Higher Education, 18(4), 401-413. http://dx.doi.org/10.1080/13562517.2012.752726.

Davidson, C. (2011). Now you see it: How the brain science of attention will change the way we live, work, and learn. New York: Viking.

Davies, W.M. (2009). Groupwork as a form of assessment: Common problems and recommended solutions. Higher Education, 58(4), 563-584.

Davis, R., \& Shadle, M. (2000). Building a mystery: Alternative research writing and the academic act of seeking. College Composition and Communication, 51(3), 417-446.

Dubois, B. (1985). Poster sessions at biomedical meetings: Design and presentation. The ESP Journal, 4(1), 37-48.

Earl, L. M. (2013). Assessment as learning: Using classroom assessment to maximize student learning (2nd ed.). Thousand Oaks, California: Corwin.

Emerson, L., Rees, M., \& MacKay, B. (2005). Scaffolding academic integrity: Creating a learning context for teaching referencing skills. Journal of University Teaching \& Learning Practice, 2(3), 13-24. 
Etkina, E., \& Andre, K. (2002). Weekly reports: Student reflections on learning: An assessment tool based on student and teacher feedback. Journal of College Science Teaching, 31(7), 476-480.

Falchikov, N. (2005). Improving assessment through student involvement: Practical solutions for aiding learning in higher and further education. New York: Routledge.

Gipps, C. (1994). A fair test? Assessment, achievement and equity. Milton Keynes: Open University Press.

Hellsten, M., \& Prescott, A. (2004). Learning at university: The international student experience. International Education Journal, 5(3), 344-351.

Higbee, J., \& Thomas, P. (2000). Preventing academic dishonesty. Research and Teaching in Developmental Education, 17(1), 63-66.

Howard, R., \& Robillard, A. (2008). Pluralizing plagiarism: Identities, contexts, pedagogies. Portsmouth: Boynton Cook.

Hydo, S. K., Marcyjanik, D. L., Zorn, C. R., \& Hooper, N. M. (2007). Art as a scaffolding teaching strategy in baccalaureate nursing education. International Journal of Nursing Education Scholarship, 4(1), 1-13. http://dx.doi.org/10.2202/1548-923X.1330

Jantke, K. P., Knauf, R., \& Gonzalez, A. J. (2006). Storyboarding for playful learning. In Reeves, T. \& Yamashita, S. (eds.), Proceedings of World Conference on e-Learning in Corporate, Government, Healthcare, and Higher Education 2006. Chesapeake, VA: AACE, 31743182.

Jarvis, L., Cain, J. (2003). Diversifying assessment 2: Posters and oral presentations in undergraduate history of science. PRS-LTSN Journal, 2(2), 50-72.

Lang, J. M. (2013). Cheating lessons: Learning from academic dishonesty. Cambridge, MA: Harvard University Press.

Macdonald, R., \& Carroll, J. (2006). Plagiarism--a complex issue requiring a holistic institutional approach. Assessment \& Evaluation in Higher Education, 31(2), 233-245. http://dx.doi.org/10.1080/02602930500262536.

McCabe, DI, \& Trevino, L.K). 1997). Individual and contextual influences on academic dishonesty: A multicampus investigation. Research in Higher Education, 38, 379-396.

McCabe, D. I. (2012). Cheating in college: Why students do it and what wducators can do about it. Baltimore: Johns Hopkins University Press.

McNamara, J., Larkin, I., \& Beatson, A. (2010). Using poster presentations as assessment of work integrated learning. Proceedings of the Australian Collaborative Education Network National Conference. Perth: Curtin University of Technology.

Mills, G. E. (2000). Action research: A guide for the teacher researcher. Upper Saddle River, New Jersey: Prentice-Hall, Inc.

Murdock, T. B., \& Anderman, E. M. (2006). Motivational perspectives on students cheating: Toward an integrated model of academic dishonesty. Educational Psychologist, 41(3), 129-145. http://dx.doi.org/10.1207/s15326985ep4103_1.

Murtagh, L., \& Webster, M. (2010). Scaffolding teaching, learning and assessment in higher education. Teacher Advancement Network Journal, 1(2), http://bit.ly/tyfJ5M. Retrieved 14 June 2016.

Oakley, B. (2002). It takes two to tango: How 'good' students enable problematic behavior in teams. Journal of Student Centered Learning, 1(1), 19-27.

Journal of the Scholarship of Teaching and Learning, Vol. 18, No. 4, December 2018.

josotl.indiana.edu 
Park, C. (2003). In Other (People's) Words: plagiarism by university students--literature and lessons. Assessment and Evaluation in Higher Education, 28(5), 471-488. http://dx.doi.org/10.1080/02602930301677.

Payne, S. A. (1994). Social accounts and metaphors about cheating. College Teaching, 42(30), 9096.

Puntambekar, S., \& Hübscher, R. (2005). Tools for scaffolding students in a complex learning environment: what have we gained and what have we missed? Educational Psychologist, 40(1), 1-12.

Roth, N., \& McCabe, D. L. (1995). Communication strategies for addressing academic dishonesty. Journal of College Student Development, 56(6), 531-541.

Roundtree, A. (2010). Posters for humanities and social sciences. Student Research Conference, University of Houston.

https://www.uhd.edu/academics/sciences/scholars/Documents/workshop-poster.pdf.

Accessed 31 May 2017.

Sagor, R. (2000). Guiding school improvement with action research. Alexandria, VA: Association for Supervision and Curriculum Development.

Saye, J., \& Brush, T. (2002). Scaffolding critical reasoning about history and social issues in multimedia-supported learning environments. ETR\&D, 77-96. http://dx.doi.org/10.1007/BF02505026.

Sharp, S. (2006). Deriving individual student marks from a tutor's assessment of group work. Assessment and Evaluation in Higher Education, 31(3), 329-343. http://dx.doi.org/10.1080/02602930500352956.

Stefani, L., \& Carroll, J. (2001). A briefing on plagiarism. Learning and Teaching Support Network Generic Centre Assessment Series.

Stewart, T. (2008). Meta-reflective service learning poster fairs: purposive pedagogy for preservice teachers. Journal for the Scholarship of Teaching and Learning, 8(3), 79-102.

StoryBoardThat! (2017, May 31). Retrieved from http://www.storyboardthat.com/.

Straw, D. (2002, July 8). The plagiarism of generation 'why not?'. Community College Week, 14(24), 4-7.

Thorley, L., \& Gregory, R., (eds.). (1994). Using group-based learning in higher education. London: Kogan Page.

Vygotsky, L. (1978). Mind in society: The development of higher psychological processes. Cambridge, MA: Harvard University Press.

Wimpfheimer, T. (2004). Peer-evaluated poster sessions: An alternative method to grading general chemistry laboratory work. Journal of Chemistry Education, 93(9), 1521-1527, http://dx.doi.org/10.1021/ed081p177

Wojtas, O. (1999, August 27). Accused students claim they 'cooperated' not collaborated. Times Higher Education Supplement, 36.

Wood, D., Bruner, J., \& Ross, G. (1976). The role of tutoring in problem solving. Journal of Child Psychology \& Psychiatry \& Allied Disciplines, 17(2), 89-100. 